\title{
PHYSICOCHEMICAL CHARACTERIZATION OF BANANA FRUIT BY UNIVARIATE AND MULTIVARIATE PROCEDURES
}

\author{
CARACTERIZAÇÃO FÍSICO-QUÍMICA DE FRUTOS DE BANANEIRA POR \\ PROCEDIMENTOS UNI E MULTIVARIADOS
}

\author{
Ana da Silva LÉDO ${ }^{1}$; Tatiana Nascimento SILVA² Carlos Roberto MARTINS $^{3}$; \\ Ana Veruska Cruz da SILVA ${ }^{1}$; Carlos Alberto da Silva LÉDO ${ }^{4}$; Edson Perito AMORIM ${ }^{4}$ \\ 1. Embrapa Tabuleiros Costeiros, Aracaju, SE, Brasil. ana.ledo@embrapa.br; 2. Universidade Federal de Sergipe, São Cristovão, SE, \\ Brasil; 3. Embrapa Clima Temperado, Pelotas, RS, Brasil; 4. Embrapa Mandioca e Fruticultura Tropical, Cruz das Almas, BA, Brasil.
}

\begin{abstract}
Breeding genotypes need to be characterized and evaluated in different soil and climatic conditions. There are few studies on association between characters evaluated and their contribution to banana genetic diversity, being essential to guide genetic breeding programs. This study aimed to evaluate the physicochemical characters of banana genotypes, to estimate associations between characters, to determine the relative importance of characters to study on genetic dissimilarity, and to indicate new genotypes to coastal plain region of Sergipe. Fruits from thirteen genotypes were used: Prata (FHIA-18, BRS Platina, PV94-01, BRS Garantida, YB42-47, Pacovan, and Prata Anã), Maçã (BRS Princesa, BRS Tropical, and Maçã), Ibota (Caipira), Gros Michel (Bucaneiro), and Mysore (Thap Maeo). The experimental design was randomized blocks, with thirteen genotypes and three replications. There is physicochemical variability of fruits between genotypes of same genomic group and subgroup, and between hybrids originated from same progenitor. Content of total sugars has greater contribution to genetic diversity among the genotypes, followed by fruit mass and pulp mass, and starch content in two cycles. Associations between fruit length, fruit diameter, and fruit mass and pulp mass in two production cycles based on phenotypic correlation are highly significant. Hybrids FHIA-18, PA94-01, YB42-47, and BRS Tropical, BRS Princesa, and Bucaneiro cultivars are promising for recommendation on coastal plain regions.
\end{abstract}

KEYWORDS: Musa spp. Cultivars. Hybrids.

\section{INTRODUCTION}

Banana tree (Musa spp.) is one of the most important fruits being grown in approximately 150 countries (FAO 2016), part of human food in different socioeconomic classes by providing high nutraceutical value (ANJUM et al., 2014; SRIVASTAVA et al., 2015), ease of in natura consumption, low cost, and organoleptic characteristics that appeal most of the population.

Brazil has been raising its production and outstanding among the main global producers, occupying the fifth place in 2014 (FAOstat, 2017), with a production in 2016 around 6,962,134 tons in 516,980 hectares (IBGE, 2017).

Genotypes from genetic breeding program need to be characterized and evaluated in different areas of production and soil and climate conditions (SILVA et al., 2016), being relevant to evaluate field agronomic characteristics, as well as to characterize post-harvest attributes, allowing the identification of promising cultivars, for breeding programs or indication for farmers. Studies have been published in different soil and climatic conditions on physicochemical and metabolic characterization of banana fruits (SILVA et al.,
2006; 2016; PIMENTEL et al., 2010; MARQUES et al., 2011; BORGES et al., 2011; 2014; RIBEIRO et al., 2012; GODOY et al., 2013; MENDONÇA et al., 2013; RIBEIRO et al., 2016; ROSA, 2016). However, there are few studies on the association between the evaluated characters and their contribution to genetic diversity, thus being essential to guide genetic breeding programs.

This study aimed to evaluate the physicochemical characters of fruits of banana genotypes, to estimate correlations, to determine the relative importance of the characters to the study on genetic dissimilarity, and to indicate new genotypes to the coastal plain region of Sergipe.

\section{MATERIAL AND METHODS}

Experiment assay was conducted from February 2012 to June 2013 in Jorge Sobral Experimental Field, in Nossa Senhora das Dores, SE, Brazil $\left(10^{\circ} 2^{\prime} ' \mathrm{~S}\right.$ and $\left.37^{\circ} 11^{\prime} \mathrm{W}\right)$, and average altitude of $208 \mathrm{~m}$. Climate of region is semi-humid, with annual average rainfall of $1,161 \mathrm{~mm}$, average air temperature of $25^{\circ} \mathrm{C}$, and relative humidity of $77 \%$. Soil of the area was classified as Typical Dystrophic Cohesive Yellow Latosol (Oxisols), 
moderate A horizon, mid/loamy texture, plain. It presents average fertility, with low contents of aluminum $\left(\mathrm{H}+\mathrm{Al}=32.98 \mathrm{mmolc}^{-3}\right)$, average acidity $(\mathrm{pH}=5.52)$, average levels of calcium and magnesium $\left(\mathrm{Ca}+\mathrm{Mg}=38.333 \mathrm{mmolc}^{-3}\right)$, low contents of phosphorus $\left(\mathrm{P}=6.3 \mathrm{mg} \mathrm{dm}^{-3}\right)$ and potassium $\left(\mathrm{K}=35.105 \mathrm{mg} \mathrm{dm}^{-3}\right)$, and low organic matter content $\left(\mathrm{OM}=19.8 \mathrm{~g} \mathrm{~kg}^{-1}\right)$. Micropropagated banana seedlings were planted in $3.00 \mathrm{~m} \times 2.00 \mathrm{~m}$ spacing, under micro sprinklers irrigation system in view of the crop water demand. Control of scrublands, defoliation, of fertilizer foundation and cover, thinning, and other practices have been applied according to recommendations for the culture (BORGES; SOUZA, 2004).

Fruits were used in the second and third production cycles of thirteen banana genotypes, being from groups Prata (FHIA-18, BRS Platina, PA94-01, BRS Garantida, Pacovan, and Prata Anã), Maçã (BRS Princesa, BRS Tropical, YB42-47, and Maçã), Ibota (Caipira), Gros Michel (Bucaneiro), and Mysore (Thap Maeo), harvested when the first bunch featured greenish color with yellow traces, without corners and rounded sides (stage 2), and later placed on the counter at room temperature (average of $26^{\circ} \mathrm{C}$ ) until its complete maturation (stage 6).

Physical characters of fruit evaluated were: fruit length $(\mathrm{cm})$, fruit diameter $(\mathrm{cm})$, fruit mass $(\mathrm{g})$, pulp mass (g), and pulp/peel ratio, determined by the quotient of mass the parts.

For chemical characters, after obtaining a homogeneous paste by grinding two fruits of each bunch/cluster/cultivar in a blender, we determined: contents of soluble solids (SS), reading in table refractometer (AOAC, 2012), expressed in ${ }^{\circ}$ Brix, $\mathrm{pH}$ on a sample of $10 \mathrm{~g}$ of crushed pulp diluted in 90 $\mathrm{mL}$ of distilled water with direct reading on digital pH meter (INSTITUTO ADOLFO LUTZ, 2005), total of titratable acid (TTA) at a sample of $5 \mathrm{~g}$ of crushed pulp diluted in $50 \mathrm{~mL}$ of distilled water with three drops of phenolphthalein solution to $1 \%$ as standard indicator with $0.1 \mathrm{~N}$ sodium hydroxide, expressed in \% of malic acid (INSTITUTO ADOLFO LUTZ, 2005) and SS/TTA obtained by the ratio between the values of soluble solids (SS) and total titratable acidity (TTA).

Total sugars were quantified by spectrophotometry at a wavelength of $620 \mathrm{~nm}$ using a standard curve of fructose $\left(100 \mathrm{mg} \mathrm{mL}^{-1}\right)$ of $0-100$ $\mathrm{mg}$ range and expressed in percentage of glucose, according to Trevelyan; Harrison (1952). Reducing sugars were quantified by the reaction of banana pulp solution with Fehling's solution, according to methodology of Instituto Adolfo Lutz (1985). Starch content was obtained by Antrona method proposed by Trevelyan; Harrison (1952), expressed in percentage.

Experimental design was randomized blocks, with thirteen treatments (genotypes) and three replications. Each plot consisted of a hand composed of five fruits per bunch. For statistical analysis of physicochemical variables of the fruits were considered the average values of the second and third production cycles.

Averages of physicochemical variables of the fruits were submitted to analysis of variance, by $F$ test and, when significant, grouped by Scott-Knott test at 5\% probability level. Genetic dissimilarity averages were calculated using the Euclidean distance. Main components analysis was performed using the Singh criterion (1981). Were calculated all the possible associations between characters based on Pearson correlation. All analyses were carried out in the statistical program Genes (CRUZ, 2013).

\section{RESULTS AND DISCUSSION}

There were significant differences between genotypes for physical characters of the fruits evaluated (Table 1).

Genotypes were grouped into three groups for the fruit length being the largest obtained by Bucaneiro $(21.57 \mathrm{~cm})$. In studies conducted by Carvalho et al. (2011) in Belém, PA, Brazil, Maçã group cultivars: Caipira $(11.19 \mathrm{~cm})$, Thap Maeo $(10.44 \mathrm{~cm})$, and Tropical $(10.55 \mathrm{~cm})$ reached lower values compared with the same cultivars in this study (14.22; 13.74 and $17.14 \mathrm{~cm}$, respectively). In dystrophic red Latosol (Oxisol) of Paraná, Borges et al. (2011) also observed smaller fruit length for the genotypes of Maçã group, FHIA-18, Prata Anã. However, the hybrids PA94-01 and BRS Platina have achieved higher values $(19 \mathrm{~cm})$ than those obtained in yellow latosol of the coastal plain region (17.47 and $14.06 \mathrm{~cm}$, respectively). Fruit length is an important physical character for banana classification ensuring homogeneity of the marketing (PBM \& PIF, 2006) and, consequently for remuneration (AZEVEDO et al., 2010). 
Table 1. Average values of physical characteristics of banana tree genotypes in the second and third production cycles - fruit length (FL), fruit diameter (FD), fruit mass (FM), pulp mass (PM), and pulp:peel ratio $(\mathrm{PPR})^{(1)}$.

\begin{tabular}{llllll}
\hline Genotypes & FL $(\mathrm{cm})$ & FD $(\mathrm{cm})$ & FM $(\mathrm{g})$ & PM $(\mathrm{g})$ & PPR \\
\hline FHIA-18 & $17.36 \mathrm{~b}$ & $3.71 \mathrm{a}$ & $130.37 \mathrm{~b}$ & $86.53 \mathrm{c}$ & $1.97 \mathrm{~b}$ \\
BRS Platina & $14.06 \mathrm{c}$ & $3.15 \mathrm{~b}$ & $87.65 \mathrm{c}$ & $61.81 \mathrm{~d}$ & $2.62 \mathrm{~b}$ \\
YB42-47 & $13.67 \mathrm{c}$ & $3.88 \mathrm{a}$ & $107.51 \mathrm{c}$ & $85.58 \mathrm{c}$ & $3.92 \mathrm{a}$ \\
PA94-01 & $17.47 \mathrm{~b}$ & $3.46 \mathrm{~b}$ & $123.35 \mathrm{~b}$ & $86.36 \mathrm{c}$ & $2.43 \mathrm{~b}$ \\
BRS Garantida & $17.69 \mathrm{~b}$ & $4.24 \mathrm{a}$ & $188.02 \mathrm{a}$ & $120.98 \mathrm{~b}$ & $1.92 \mathrm{~b}$ \\
Pacovan & $13.67 \mathrm{c}$ & $3.36 \mathrm{~b}$ & $88.53 \mathrm{c}$ & $59.73 \mathrm{~d}$ & $2.24 \mathrm{~b}$ \\
Prata Anã & $13.87 \mathrm{c}$ & $3.21 \mathrm{~b}$ & $87.09 \mathrm{c}$ & $60.00 \mathrm{~d}$ & $2.27 \mathrm{~b}$ \\
BRS Princesa & $13.42 \mathrm{c}$ & $3.45 \mathrm{~b}$ & $90.71 \mathrm{c}$ & $69.57 \mathrm{~d}$ & $3.48 \mathrm{a}$ \\
BRS Tropical & $17.14 \mathrm{~b}$ & $3.93 \mathrm{a}$ & $143.48 \mathrm{~b}$ & $113.98 \mathrm{~b}$ & $4.08 \mathrm{a}$ \\
Maçã & $15.74 \mathrm{c}$ & $3.90 \mathrm{a}$ & $137.22 \mathrm{~b}$ & $112.10 \mathrm{~b}$ & $4.05 \mathrm{a}$ \\
Caipira & $14.22 \mathrm{c}$ & $3.40 \mathrm{~b}$ & $102.20 \mathrm{c}$ & $80.26 \mathrm{c}$ & $3.80 \mathrm{a}$ \\
Bucaneiro & $21.57 \mathrm{a}$ & $3.79 \mathrm{a}$ & $193.96 \mathrm{a}$ & $146.12 \mathrm{a}$ & $3.11 \mathrm{a}$ \\
Thap Maeo & $13.74 \mathrm{c}$ & $3.73 \mathrm{a}$ & $117.08 \mathrm{~b}$ & $91.58 \mathrm{c}$ & $3.97 \mathrm{a}$ \\
\hline CV (\%) & 11.45 & 10.51 & 20.85 & 20.04 & 23.00
\end{tabular}

(1) Averages followed by the same letter in column belong to the same group according to the clustering method of Scott-Knott at $5 \%$ of significance; CV (coefficient of variation).

Regarding the fruit diameter, two groups were formed: first, with higher averages, consisting of FHIA-18, YB42-47, BRS Garantida, BRS Tropical, Maçã, Bucaneiro, and Thap Maeo, ranging from 3.71 to $4.24 \mathrm{~cm}$; and second formed by BRS Platina, PA94-01, Pacovan, Prata Anã, BRS Princesa, and Caipira, with amplitude ranging from 3.15 to $3.46 \mathrm{~cm}$. Differentiated responses between genotypes for this characteristic were also observed by Borges et al. (2011), Carvalho et al. (2011) and Marques et al. (2011). However, Rosa (2016) also observed non-significant difference between Prata Anã, BRS Princesa e BRS Platina. Despite BRS Platina is a hybrid, for this character, in the present work, was not superior to its genitor as reported by Silva et al. (2013). Both fruit diameter and fruit length are important for trade classification (DONATO et al., 2009).

Considering the fruit mass, the first group was constituted by Bucaneiro (193.96 g) and BRS Garantida (188.02 g). The FHIA-18, PA94-01, BRS Tropical, Maçã, and Thap Maeo genotypes presented average values between 117.08 and $143.48 \mathrm{~g}$, and third group, formed by BRS Platina, YB42-47, Pacovan, Prata Anã, BRS Princesa, and Caipira hybrids, ranged from 87.09 to $107.51 \mathrm{~g}$. Productivity, according to Lessa et al. (2012), is associated with fruit mass and number of fruits. For pulp mass, four groups were formed, and the Bucaneiro presented the greater mass (146.12 g), followed by BRS Garantida (120.98 g), BRS Tropical (113.98 g), and Maçã (112.10 g). FHIA18, YB42-47, PA94-01, Caipira, and Thap Maeo genotypes the third group; PA42-44, Pacovan, Prata Anã, and BRS Princesa the fourth group. BRS Princesa cultivar obtained smaller fruit mass and pulp mass (90.71 and $69.57 \mathrm{~g}$, respectively) when compared with other genotypes of Maçã group. However, in Fluvents with average fertility in Baixo São Francisco, SE, Lédo et al. (2008) obtained greater fruit mass for BRS Princesa $(132.4 \mathrm{~g})$. This fact contributes to the genotype $\mathrm{x}$ environment interaction a mentioned by Léon et al. (2016). Probably the environmental conditions, as humid, at Baixo São Francisco, SE was more adequate to BRS Princesa development than the semi-arid region.

First group to pulp/peel ratio, with higher averages, consisted of the genotypes YB42-47, BRS Princesa, BRS Tropical, Maçã, Caipira, Bucaneiro, and Thap Maeo; and the second, by BRS Platina, FHIA-18, PA94-01, Pacovan, Prata Anã, and BRS Garantida. Pulp yield is a feature of economic importance for the industry, since it is directly related to yield in processing fruits (CHITARRA; CHITARRA, 2005).

Overall, it has not been verified the grouping of all Prata Anã hybrids in groups higher than its progenitor regarding physical characters, with the exception of PA94-01 and FHIA-18 for length and fruit mass, corroborating Donato et al. 
(2009), observed the same behavior of hybrid BRS Platina and its progenitor, Prata Anã, in relation to BRS FHIA-18, FHIA-18, and FHIA-01 (BRS Maravilha).

Variety observed in the responses of genotypes regarding physical characters, depending on the location and type of soil, is expected. According to Léon et al. (2016) expression of a phenotype is a function of the genotype, the environment and differential phenotypic response of genotypes to different environments, also known as genotype by environment ( $\mathrm{G} \mathrm{X} \mathrm{E)}$ interaction. Kang et al. (1991) cited by Tonk et al. (2011) indicated that selection based on yield only may not always be adequate when genotype $\mathrm{x}$ environment interaction is significant. These factors reinforce the need for evaluation of genotypes in different environments and crop conditions for recommendation purposes.

There were significant differences between genotypes for contents of soluble solids, titratable total acidity, and reducing sugars (Table 2). Four groups were formed for soluble solids content, being the first consisting of Pacovan, BRS Princesa, and Prata Anã; the second, by Maçã; the third, by FHIA18, YB42-47, BRS Garantida, Caipira, and Thap
Maeo; and the fourth, with the lowest averages, by BRS Platina, PA94-01, BRS Tropical, and Bucaneiro.

Genotypes were gathered into two groups regarding total titratable acidity: the first was formed by BRS Tropical, BRS Princesa, Maçã, Pacovan, and YB42-47, ranging from 0.93 to $1.27 \%$ malic acid; and the second, by FHIA-18, PA94-01, Thap Maeo, BRS Garantida, Caipira, BRS Platina, Prata Anã, and Bucaneiro, ranging from 0.67 to $0.83 \%$ malic acid. High total titratable acidity is a desirable feature for the industry (Godoy, 2010), which emphasizes the suitability of Bucaneiro for processing industry. In a study by Pimentel et al. (2010), conducted in the North of Minas Gerais, Prata Anã presented a higher average of total titratable acidity $(0.69 \%)$ compared with BRS Platina $(0.65 \%)$, in contrast with the results in which both genotypes did not differ. Ribeiro et al. (2012), evaluating the behavior of cultivars in organic and conventional management in Cruz das Almas, BA, Brazil, verified Caipira cultivar significantly differed from others in the organic system, with the lowest acidity $(0.11 \%)$, and the largest in BRS Tropical $(0.23 \%)$ on the conventional system.

Table 2. Average values of physicochemical characteristics of banana genotypes in the second and third production cycles - SS ( ${ }^{\circ}$ Brix), TTA (\% malic acid), RS (\% glucose), TS (\% glucose), and STA (\%).

\begin{tabular}{llllllll}
\hline Genótipos & SS & ATT & RAT & AR & TS & STA & pH \\
\hline FHIA-18 & $23.53 \mathrm{c}$ & $0.83 \mathrm{~b}$ & $28.83 \mathrm{a}$ & $8.99 \mathrm{~b}$ & $19.49 \mathrm{a}$ & $1.15 \mathrm{a}$ & $4.85 \mathrm{~b}$ \\
BRS Platina & $22.05 \mathrm{~d}$ & $0.67 \mathrm{~b}$ & $33.54 \mathrm{a}$ & $15.07 \mathrm{a}$ & $20.46 \mathrm{a}$ & $0.92 \mathrm{a}$ & $5.06 \mathrm{a}$ \\
YB42-47 & $24.34 \mathrm{c}$ & $0.93 \mathrm{a}$ & $27.80 \mathrm{a}$ & $7.79 \mathrm{~b}$ & $18.63 \mathrm{a}$ & $1.77 \mathrm{a}$ & $4.74 \mathrm{~b}$ \\
PA94-01 & $22.26 \mathrm{~d}$ & $0.83 \mathrm{~b}$ & $28.86 \mathrm{a}$ & $13.67 \mathrm{a}$ & $18.50 \mathrm{a}$ & $0.92 \mathrm{a}$ & $4.74 \mathrm{~b}$ \\
BRS Garantida & $24.05 \mathrm{c}$ & $0.71 \mathrm{~b}$ & $34.24 \mathrm{a}$ & $15.61 \mathrm{a}$ & $18.10 \mathrm{a}$ & $2.81 \mathrm{a}$ & $4.74 \mathrm{~b}$ \\
Pacovan & $28.48 \mathrm{a}$ & $0.93 \mathrm{a}$ & $30.62 \mathrm{a}$ & $19.33 \mathrm{a}$ & $16.01 \mathrm{a}$ & $1.96 \mathrm{a}$ & $4.85 \mathrm{~b}$ \\
Prata Anã & $27.58 \mathrm{a}$ & $0.67 \mathrm{~b}$ & $41.80 \mathrm{a}$ & $14.10 \mathrm{a}$ & $18.46 \mathrm{a}$ & $2.34 \mathrm{a}$ & $4.66 \mathrm{~b}$ \\
BRS Princesa & $28.29 \mathrm{a}$ & $1.10 \mathrm{a}$ & $27.62 \mathrm{a}$ & $7.18 \mathrm{~b}$ & $18.28 \mathrm{a}$ & $2.00 \mathrm{a}$ & $4.71 \mathrm{~b}$ \\
BRS Tropical & $22.63 \mathrm{~d}$ & $1.27 \mathrm{a}$ & $19.00 \mathrm{a}$ & $16.09 \mathrm{a}$ & $17.56 \mathrm{a}$ & $1.87 \mathrm{a}$ & $4.73 \mathrm{~b}$ \\
Maçã & $25.83 \mathrm{~b}$ & $1.08 \mathrm{a}$ & $25.33 \mathrm{a}$ & $10.24 \mathrm{~b}$ & $20.05 \mathrm{a}$ & $1.65 \mathrm{a}$ & $4.67 \mathrm{~b}$ \\
Caipira & $23.31 \mathrm{c}$ & $0.71 \mathrm{~b}$ & $34.46 \mathrm{a}$ & $8.32 \mathrm{~b}$ & $17.26 \mathrm{a}$ & $1.87 \mathrm{a}$ & $5.10 \mathrm{a}$ \\
Bucaneiro & $20.65 \mathrm{~d}$ & $0.67 \mathrm{~b}$ & $31.47 \mathrm{a}$ & $14.75 \mathrm{a}$ & $21.68 \mathrm{a}$ & $0.88 \mathrm{a}$ & $5.27 \mathrm{a}$ \\
Thap Maeo & $23.11 \mathrm{c}$ & $0.79 \mathrm{~b}$ & $29.70 \mathrm{a}$ & $10.63 \mathrm{~b}$ & $18.82 \mathrm{a}$ & $1.78 \mathrm{a}$ & $4.67 \mathrm{~b}$ \\
\hline CV $(\%)$ & 5.62 & 24.21 & 21.87 & 33.23 & 7.05 & 43.57 & 4.09
\end{tabular}

Averages followed by the same uppercase letter in the column belong to the same group according; to the clustering method of ScottKnott at $5 \%$ of significance. CV: coefficient of variation; SS: soluble solids; TTA: titratable total acidity; RAT: SS/TTA, RS - reducing sugars; TS: total sugars; and STA: starch

Pacovan, BRS Tropical, BRS Garantida, BRS Platina, Prata Anã, Bucaneiro, and PA94-01 genotypes formed the group with the highest contents of reducing sugars, ranging from 13.67 to $19.3 \%$, and the second group, formed by Thap Maeo, Maçã, FHIA-18, Caipira, YB42-47, and BRS 
Princesa, ranging from 7.18 to $10.24 \%$. Bucaneiro, Caipira and, BRS Platina genotypes presented the highest $\mathrm{pH}(5.27 ; 5.10$, and 5.06 respectively), and FHIA-18, YB42-47, PA94-01, BRS Garantida, Pacovan, Prata Anã, BRS Princesa, BRS Tropical, Maçã, and Thap Maeo genotypes formed the second group, with $\mathrm{pH}$ ranging from 4.66 to 4.85 . Results obtained by Bezerra and Dias (2009), Roque et al. (2014) and Castrini et al. (2015), in different environments, did not present great variations as compared with those obtained in the present study. Probably the $\mathrm{pH}$ is a characteristic not greatly affected by the genotype $\mathrm{x}$ environment interaction.

There were no significant differences between genotypes for SS/TTA ratio, total sugars, and starch. SS/TTA ratio ranged from 19.00 (BRS Tropical) to 41.80 (Prata Anã). In studies conducted by Bezerra and Dias (2009), Prata Anã genotype presented average value (28.13) quite below the one found in this study. According to reports by Chitarra and Chitarra (2005), this variable has been applied to the evaluation of taste in relationship between soluble solids and titratable acidity. There was no significant difference between genotypes for total sugars and starch, which ranged from 21.68 to $17.26 \%$ and from 0.88 to $2.81 \%$, respectively.

Associations between fruit length, fruit diameter, fruit mass and pulp mass in both production cycles based on phenotypic correlation are highly significant (Table 3). There was significant negative correlation of these variables with the pulp/peel ratio.

The $\mathrm{pH}$ presented significant negative correlation with soluble solids in second cycle and starch in second and third cycles. According Godoy (2010) $\mathrm{pH}$ presented moderate negative correlation with reducing sugars, unlike the titratable total acidity, that had positive correlation with these sugars. Total titratable acidity was highly negatively correlated with SS/TTA, an expected result, and relation between total sugars and starch was significant and negative.

Table 3. Phenotypic correlations between physicochemical characters of banana tree genotypes in the second and third production cycles, with the respective significance tests ${ }^{(2)}$.

\begin{tabular}{|c|c|c|c|c|c|c|c|c|c|c|c|}
\hline \multicolumn{12}{|c|}{$2^{\circ}$ Production Cycle } \\
\hline & FD & MFP & MFWP & PPR & $\mathrm{pH}$ & SS & TTA & SS/TTA & $\mathrm{RS}$ & $\mathrm{TS}$ & STA \\
\hline LF & $0.683^{* *}$ & $0.878 * *$ & $0.846^{* *}$ & $-0.236^{\mathrm{ns}}$ & $0.364^{\mathrm{ns}}$ & $-0.569^{*}$ & $0.035^{\text {ns }}$ & $-0.323^{\mathrm{ns}}$ & $0.126^{\text {ns }}$ & $0.162^{\mathrm{ns}}$ & $0.060^{\mathrm{ns}}$ \\
\hline FD & & $0.845^{* *}$ & $0.830^{* *}$ & $-0.002^{\mathrm{ns}}$ & $-0.027^{\mathrm{ns}}$ & $-0.206^{\mathrm{ns}}$ & $0.306^{\mathrm{ns}}$ & $-0.471^{*}$ & $0.099^{\text {ns }}$ & $-0.101^{\mathrm{ns}}$ & $0.275^{\text {ns }}$ \\
\hline FM & & & $0.962 * *$ & $-0.137^{\mathrm{ns}}$ & $0.213^{\text {ns }}$ & $-0.485^{*}$ & $0.138^{\mathrm{ns}}$ & $-0.395^{*}$ & $0.203^{\text {ns }}$ & $0.085^{\text {ns }}$ & $0.228^{\mathrm{ns}}$ \\
\hline PM & & & & $0.104^{\mathrm{ns}}$ & $0.216^{\mathrm{ns}}$ & $-0.502 * *$ & $0.174^{\mathrm{ns}}$ & $-0.407^{*}$ & $0.107^{\text {ns }}$ & $0.223^{\mathrm{ns}}$ & $0.081^{\mathrm{ns}}$ \\
\hline PPR & & & & & $-0.001^{\mathrm{ns}}$ & $0.002^{\mathrm{ns}}$ & $0.196^{\mathrm{ns}}$ & $-0.079^{\mathrm{ns}}$ & $-0.325^{\mathrm{ns}}$ & $0.459^{*}$ & $-0.384^{\mathrm{ns}}$ \\
\hline $\mathrm{pH}$ & & & & & & $-0.306^{\mathrm{ns}}$ & $-0.376^{\mathrm{ns}}$ & $0.239^{\mathrm{ns}}$ & $0.205^{\mathrm{ns}}$ & $0.248^{\text {ns }}$ & $-0.138^{\mathrm{ns}}$ \\
\hline SS & & & & & & & $0.174^{\mathrm{ns}}$ & $0.249^{\mathrm{ns}}$ & $0.034^{\mathrm{ns}}$ & $-0.373^{\mathrm{ns}}$ & $0.421 *$ \\
\hline TTA & & & & & & & & $-0.831^{* *}$ & $-0.057^{\mathrm{ns}}$ & $-0.149^{\mathrm{ns}}$ & $0.065^{\text {ns }}$ \\
\hline SS/TTA & & & & & & & & & $0.144^{\mathrm{ns}}$ & $0.011^{\mathrm{ns}}$ & $0.046^{\mathrm{ns}}$ \\
\hline RS & & & & & & & & & & $-0.294^{\mathrm{ns}}$ & $0.165^{\text {ns }}$ \\
\hline TS & & & & & & & & & & & $-0.521 * *$ \\
\hline
\end{tabular}

$3^{\circ}$ Production Cycle

\begin{tabular}{|c|c|c|c|c|c|c|c|c|c|c|c|}
\hline & FD & FM & $\mathrm{PM}$ & PPR & $\mathrm{pH}$ & SS & TTA & SS/TTA & $\mathrm{RS}$ & $\mathrm{TS}$ & STA \\
\hline $\mathrm{LF}$ & $0.533^{* *}$ & $0.882 * *$ & $0.838 * *$ & $-0.210^{\mathrm{ns}}$ & $0.443^{*}$ & $-0.413 *$ & $-0.010^{\mathrm{ns}}$ & $-0.164^{\mathrm{ns}}$ & $0.327^{\mathrm{ns}}$ & $0.356^{\mathrm{ns}}$ & $-0.224^{\mathrm{ns}}$ \\
\hline FD & & $0.805^{* *}$ & $0.802 * *$ & $0.014^{\mathrm{ns}}$ & $0.194^{\mathrm{ns}}$ & $-0.239^{\mathrm{ns}}$ & $0.344^{\mathrm{ns}}$ & $-0.415^{*}$ & $-0.041^{\mathrm{ns}}$ & $0.157^{\mathrm{ns}}$ & $0.303^{\text {ns }}$ \\
\hline FM & & & $0.959 * *$ & $-0.167^{\mathrm{ns}}$ & $0.247^{\mathrm{ns}}$ & $-0.371^{\mathrm{ns}}$ & $0.088^{\mathrm{ns}}$ & $-0.258^{\mathrm{ns}}$ & $0.180^{\mathrm{ns}}$ & $0.341^{\mathrm{ns}}$ & $0.018^{\mathrm{ns}}$ \\
\hline PM & & & & $0.101^{\mathrm{ns}}$ & $0.320^{\mathrm{ns}}$ & $-0.408 *$ & $0.202^{\mathrm{ns}}$ & $-0.354^{\mathrm{ns}}$ & $0.052^{\mathrm{ns}}$ & $0.275^{\text {ns }}$ & $0.040^{\text {ns }}$ \\
\hline PPR & & & & & $0.245^{\mathrm{ns}}$ & $-0.160^{\mathrm{ns}}$ & $0.360^{\mathrm{ns}}$ & $-0.259^{\mathrm{ns}}$ & $-0.516 * *$ & $-0.181^{\mathrm{ns}}$ & $-0.033^{\text {ns }}$ \\
\hline
\end{tabular}




\begin{tabular}{|c|c|c|c|c|c|c|}
\hline $\mathrm{pH}$ & $-0.445^{*}$ & $-0.232^{\mathrm{ns}}$ & $0.164^{\mathrm{ns}}$ & $0.001^{\mathrm{ns}}$ & $0.294^{\mathrm{ns}}$ & $-0.472 *$ \\
\hline SS & & $0.385^{\text {ns }}$ & $-0.115^{\mathrm{ns}}$ & $-0.204^{\mathrm{ns}}$ & $-0.281^{\mathrm{ns}}$ & $0.233^{\mathrm{ns}}$ \\
\hline TTA & & & $-0.908 * *$ & $-0.090^{\mathrm{ns}}$ & $-0.279^{\mathrm{ns}}$ & $0.290^{\mathrm{ns}}$ \\
\hline SS/TTA & & & & $-0.061^{\mathrm{ns}}$ & $0.170^{\mathrm{ns}}$ & $-0.242^{\mathrm{ns}}$ \\
\hline $\mathrm{RS}$ & & & & & $-0.147^{\mathrm{ns}}$ & $-0.104^{\mathrm{ns}}$ \\
\hline TS & & & & & & $-0.474^{\mathrm{ns}}$ \\
\hline
\end{tabular}

Analysis performed criterion by Singh (1981), to estimate the relative contribution of each variable to the study of the genetic dissimilarity, indicated that major components explained 99.17 and $98.96 \%$ of total variation between the 13 genotypes in the second and third cycles, respectively (Table 4). Characters total sugars $(60.56 \%)$, fruit mass $(18.34 \%)$, starch $(10.84 \%)$, and pulp mass $(9.43 \%)$, in the second cycle, and total sugars $(55.33 \%)$, fruit mass $(20.27 \%)$, starch $(12.67 \%)$, and pulp mass $(10.69 \%)$, in the third cycle, were those that contributed the most to the total diversity between the thirteen genotypes. The
$\mathrm{pH}, \mathrm{SS}, \mathrm{TTA}, \mathrm{SS} / \mathrm{TTA}$ ratio, and pulp/peel ratio obtained lower relative contribution, in accordance with Godoy (2010). Greatest contribution of the same characters in both cycles can reinforce these characteristics are effective for the analysis of all genotypes. Mattos et al. (2010) observed the first three main components explained $68.30 \%$ of the total variation among the 26 banana tree accessions evaluated regarding their agronomic characteristics, and the number of fruits contributed in $83.80 \%$ to variation among the fruits. Godoy (2010) also noted high contribution of sugars and low contribution of SS/TTA ratio, pulp yield, and TTA.

Table 4. Relative importance (S.j.) of physicochemical characters of fruits for genetic diversity studies in 13 banana genotypes in the second and third production cycles ${ }^{(4)}$.

\begin{tabular}{lllll}
\hline Characters & $2^{\circ}$ Cycle & \multicolumn{3}{l}{$3^{\circ}$ Cycle } \\
\cline { 2 - 5 } & S.j & S.j $(\%)$ & S.j & S.j (\%) \\
\hline LF & 1050.04 & 0.07 & 1006.58 & 0.10 \\
FD & 31.06 & 0.00 & 13.16 & 0.00 \\
FM & 289151.04 & 18.34 & 199540.78 & 20.27 \\
PM & 148770.34 & 9.43 & 105267.60 & 10.69 \\
PPR & 106.72 & 0.01 & 136.38 & 0.01 \\
pH & 5.34 & 0.00 & 8.46 & 0.00 \\
SS & 1085.40 & 0.07 & 871.04 & 0.09 \\
TTA & 5.10 & 0.00 & 8.84 & 0.00 \\
SS/TTA & 6560.22 & 0.42 & 6262.62 & 0.64 \\
RS & 4159.38 & 0.26 & 1798.00 & 0.18 \\
TS & 955110.42 & 60.56 & 544675.14 & 55.33 \\
STA & 170968.10 & 10.84 & 124748.56 & 12.67 \\
\hline
\end{tabular}

${ }^{(4)} \mathrm{S} . \mathrm{j} .:$ contribution of variable $\mathrm{x}$ to the Euclidean distance between genotypes; LF: length; of the fruit; FD: fruit diameter; FM: fruit mass; PM: pulp mass; PPR: pulp/peel ratio; pH; SS: soluble solids; TTA: titratable total acidity; RS: reducing sugar; TS: total sugar; STA: starch.

Considering the genetic dissimilarity average (1.33) of genotypes in third cycle, four groups were formed (Figure 1): G1 - FHIA-18, BRS Platina, PA94-01, BRS Garantida, YB42-47, Thap Maeo, Prata Anã, BRS Princesa, Maçã, and Pacovan; G2 - Caipira; G3 - BRS Tropical; and G4 - Bucaneiro.

The comparison of the averages, for twelve physicochemical characters under study and groups obtained, by Euclidean distance and UPGMA clustering method, allowed to infer differences between them. All genotypes of G1 present the genome B. BRS Platina, PA94-01, and FHIA-18 hybrids are genetically closer than their progenitor, Prata Anã. Expected result considering that, overall, hybrids presented better performance than progenitor's to some features. Bucaneiro presented more divergence for being a tetraploid of genome $\mathrm{A}$ (G4). 


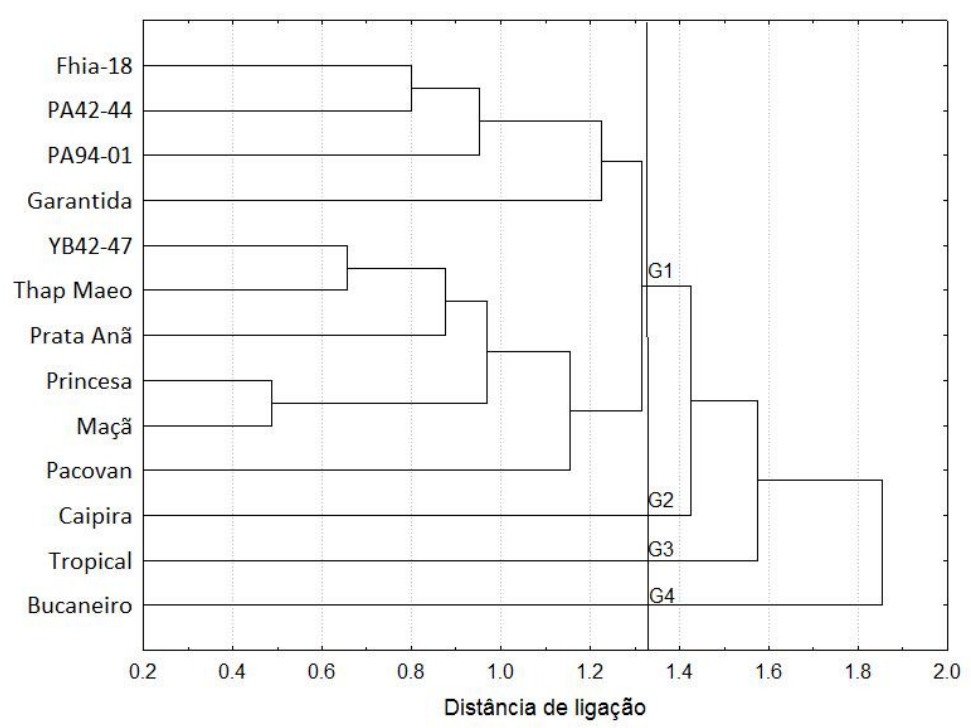

Figure 1. Dendrogram of genetic dissimilarity of 13 banana genotypes based on Euclidean distance and UPGMA clustering method in third production cycle. Groups 1 (G1), 2 (G2), 3 (G3), and 4 (G4).

\section{CONCLUSIONS}

There is physicochemical variability of fruits between the genotypes evaluated; the content of total sugars has greater contribution to genetic diversity, followed by fruit mass and pulp mass, and starch content in two production cycles.

Associations between fruit length, fruit diameter, fruit mass and pulp mass in two production cycles based on phenotypic correlation are highly significant.

BRS Platina, PA94-01, and FHIA-18 hybrids are genetically close, and Bucaneiro present greater divergence for being a tetraploid of genome A.

FHIA-18 and PA94-01 hybrids, YB42-47 and BRS Tropical, BRS Princesa, and Bucaneiro cultivars are promising for recommendation on coastal plain regions.

\section{ACKNOWLEDGEMENTS}

The authors would like to thank CAPES Coordenação de Aperfeiçoamento de Pessoal de Nível Superior and EMBRAPA- Empresa Brasileira de Pesquisa Agropecuária for financial support.

RESUMO: Genótipos melhorados necessitam ser caracterizados e avaliados em diferentes condições edafoclimáticas. Existem poucos estudos sobre a associação entre os caracteres avaliados e sua contribuição para a diversidade genética da banana, sendo imprescindíveis para orientar programas de melhoramento genético. O objetivo desse trabalho foi avaliar os caracteres físico-químicos de frutos de genótipos de bananeira, estimar as associações entre caracteres, determinar a importância relativa dos caracteres para o estudo da dissimilaridade genética e indicar novos genótipos para a região de Tabuleiros Costeiros de Sergipe. Foram utilizados frutos de treze genótipos: tipo Prata (FHIA18, BRS Platina, PV94-01, BRS Garantida, YB42-47, Pacovan e Prata-Anã), Maçã (BRS Princesa, BRS Tropical e Maçã), Ibota (Caipira), Gros Michel (Bucaneiro) e o Mysore (Thap Maeo). O delineamento experimental foi em blocos ao acaso, com treze genótipos e três repetições. Existe variabilidade físico-química dos frutos entre os genótipos do mesmo grupo genômico e subgrupo, e entre híbridos originados da mesma genitora. O teor de açúcares totais apresenta maior contribuição para a diversidade genética entre os genótipos, seguido da massa do fruto com e sem casca e teor de amido nos dois ciclos. As associações entre comprimento do fruto, o diâmetro, massa do fruto e da polpa nos dois ciclos de produção com base na correlação fenotípica são altamente significativas. Os híbridos FHIA-18, PA94-01, YB42-47 e as cultivares BRS Tropical, BRS Princesa e Bucaneiro são promissores para recomendação nos Tabuleiros Costeiros.

PALAVRAS-CHAVE: Musa sp. Cultivares. Híbridos. 


\section{REFERENCES}

ANJUM, S.; SUNDARAM, S.; RAI, G. K. Nutraceutical application and value addition of banana peel: a review. International Journal of Pharmacy and Pharmaceutical Sciences, Madhya Pradesh, v. 6, p. 81-85, 2014.http://innovareacademics.in/journals/index.php/ijpps/article/view/3584/1371

AZEVEDO, V. F.; DONATO, S. L. R.; ARANTES, A. M.; MAIA, V. M.; SILVA, S. O. Avaliação de bananeiras tipo Prata, de porte alto, no Semiárido. Ciência e Agrotecnologia, Lavras, v. 34, p. 1372-1380, 2010. http://dx.doi.org/10.1590/S1413-70542010000600003

AOAC - Association of Official Analytical Chemistral. Official methods of analysis of the Association of Official Analytical Chemistry. 194. ed. Maryland: AOAC International, 2012. 1115p.

BEZERRA, V. S.; DIAS, J. S. A. Avaliação físico-química de frutos de bananeiras. Acta Amazônica, Manaus, v. 39, p. 423-427, 2009. http://dx.doi.org/10.1590/S0044-59672009000200022

BORGES, A. L.; SOUZA, L. S. O cultivo da bananeira. Cruz das Almas: Embrapa Mandioca e Fruticultura, 2004. 279 p. http://frutvasf.univasf.edu.br/images/banana2.pdf

BORGES, C. V.; AMORIM, V. B. O.; RAMLOVC, F.; LEDO, C. A. S.; DONATO M.; MARASCHINC, M.; AMORIM, E. P. Characterization of metabolic profile of banana genotypes, aiming at biofortified Musa spp. cultivars. Food Chemistry, v. 145, p. 496-504, 2014. http://dx.doi.org/10.1016/j.foodchem.2013.08.041

BORGES, R. S.; SILVA, S. O.; OLIVEIRA, F. T.; ROBERTO, S. R. Avaliação de genótipos de bananeira no norte do estado do Paraná. Revista Brasileira de Fruticultura, Jaboticabal, v. 33, p. 291-296, 2011. http://dx.doi.org/10.1590/S0100-29452011005000034

CARVALHO, A. V.; SECCADIO, L. L.; MOURÃO JÚNIOR, M.; NASCIMENTO, W. O. do. Qualidade póscolheita de cultivares de bananeira do grupo Maçã, na região de Belém-PA. Revista Brasileira de Fruticultura, Jaboticabal, v. 33, p. 1095-1102, 2011.http://www.scielo.br/pdf/rbf/v33n4/v33n4a07

CHITARRA, M. I. F; CHITARRA, A. B. Pós-colheita de frutas e hortaliças: fisiologia e manuseio. Lavras: UFLA, 2005. 785p.

CRUZ, C. D. GENES - a software package for analysis in experimental statistics and quantitative genetics. Acta Scientiarum, Maringá, v. 35, n. 3, p. 271-276, 2013.

http://dx.doi.org/10.4025/actasciagron.v35i3.21251

DONATO, S. L. R.; ARANTES, A. de M.; SILVA, S. O.; CORDEIRO, Z. J. M. Comportamento fitotécnico da bananeira 'Prata-Anã' e de seus híbridos. Pesquisa Agropecuária Brasileira, Brasília, v. 44, p. 1608-1615, 2009. http://dx.doi.org/10.1590/S0100-204X2009001200007

FAOstat. Food and Agricultural Organization. Disponível em: http://faostat3.fao.org/home/E Acesso em: 10 de abr. 2017.

GODOY, R. C. B. . Estudo das variáveis de processo em doce de banana de corte elaborado com variedade resistente à Sigatoka-negra, 2010, 256p. Tese (Doutorado) - Universidade Federal do Paraná IBGE. Levantamento sistemático de produção agrícola. Disponível em: http://www.ibge.gov.br/home/estatistica/indicadores/agropecuaria/lspa/default_publ_completa.shtm Acesso em: 10 de abr. 2017

INSTITUTO ADOLFO LUTZ. Normas Analíticas do Instituto Adolfo Lutz: métodos químicos e físicos para análise de alimentos, São Paulo: IMESP, 1985. p. 49-50. 
LÉDO, A. da S.; SILVA JUNIOR, J. F.; LÉDO, C. A. da S.; SILVA, S. de O. Avaliação de genótipos de bananeira na região do Baixo São Francisco, Sergipe. Revista Brasileira de Fruticultura, Jaboticabal, v. 30, p. 691-695, 2008. http://dx.doi.org/10.1590/S0100-29452008000300022

LEON, N. ; JANNINK, J. L.; EDWARDS, J. W.; KAEPPLER, S. M. Introduction to a special issue on genotype by environment interaction. Crop Science, Madison, v. 56, n. 5, p. 2081-2089, 2016.

https://dl.sciencesocieties.org/publications/cs/pdfs/56/5/2081

LESSA, L. S.; LEDO, C. A. ; AMORIM, E. P.; SILVA, S. O. Correlação fenotípica entre caracteres de híbridos diploides (AA) de bananeira. Revista Brasileira de Fruticultura, Jaboticabal, v. 34, p. 1129-1134, 2012. http://dx.doi.org/10.1590/S0100-29452012000400021

MARQUES, P. R. R.; DONATO, S. L. R.; PEREIRA, M. C. T.; COELHO, E. F.; ARANTES, A. M. Características agronômicas de bananeiras tipo Prata sob diferentes sistemas de irrigação. Pesquisa Agropecuária Brasileira, Brasília, v. 46, n. 8., p. 852-859, 2011. https://dx.doi.org/10.1590/S0100204X2011000800010

MATTOS, L. A.; AMORIM, E. P.; AMORIM, V. B. O.; COHEN, K. O.; LEDO, C. A. S.; SILVA, S. O. Agronomical and molecular characterization of banana germplasm. Pesquisa Agropecuária Brasileira, Brasília, v. 45, p. 146-154, 2010. http://dx.doi.org/10.1590/S0100-204X2010000200005

MENDONÇA, K. H.; DUARTE, D. A. S.; COSTA, V. A. M.; MATOS, G. R.; SELEGUINI, A. Avaliação de genótipos de bananeira em Goiânia, estado de Goiás. Revista Ciência Agronômica, Fortaleza, v. 44, p. 652660, 2013. http://www.ccarevista.ufc.br/seer/index.php/ccarevista/article/view/1937/846

PIMENTEL, R. M. de A.; GUIMARÃES, F. N.; SANTOS, V. M. dos; RESENDE, J. C. F. de. Qualidade póscolheita dos genótipos de banana PA42-44 e Prata Anã cultivados no norte de Minas Gerais. Revista

Brasileira de Fruticultura, Jaboticabal, v. 32, p. 407-413, 2010.

http://dx.doi.org/10.1590/S0100-29452010005000047

PBMH \& PIF - PROGRAMA BRASILEIRO PARA A MODERNIZAÇÃO DA HORTICULTURA \& PRODUÇÃO INTEGRADA DE FRUTAS. Normas de classificação de banana. São Paulo: CEAGESP, 2006. (Documentos, 29)

http://www.ceagesp.gov.br/wp-content/uploads/2015/07/banana.pdf

RAMOS, D. P.; LEONEL, S.; MISCHAN, M. M. Correlações fenotípicas entre característica de produção e crescimento em genótipos de bananeira. Bioscience Journal, Uberlândia, v. 25, p. 82-89, 2009.

http://www.seer.ufu.br/index.php/biosciencejournal/article/view/7018/4650

RIBEIRO, L. R.; OLIVEIRA, L. M. de; SILVA, S. O.; BORGES, A. L. Caracterização física e química de bananas produzidas em sistemas de cultivo convencional e orgânico. Revista Brasileira de Fruticultura, Jaboticabal, v. 34, p. 774-782, 2012. http://dx.doi.org/10.1590/S0100-29452012000300017

ROQUE, R. L.; AMORIM, T. B. ; FERREIRA, C. F.; LEDO, C. A. S.; AMORIM, E. P. Desempenho agronômico de genótipos de bananeira no recôncavo da Bahia. Revista Brasileira de Fruticultura, Jaboticabal, v. 36, p. 598- 609, 2014. http://dx.doi.org/10.1590/0100-2945-361/13

SILVA, E. A.; BOLIANI, A. C.; CORRÊA, L. S. Evaluation of banana (Musa sp) cultivars in Selvíria -MS region. Revista Brasileira de Fruticultura, Jaboticabal, v. 28, p. 101-103, 2006.

http://dx.doi.org/10.1590/S0100-29452006000100028

SILVA, M. J. R. ; ANJOS, J. M. C. ; JESUS, P. R. R. ; SANTOS, G. S., LIMA, F. B. F.; RIBEIRO, V. G. (2013). Produção e caracterização da bananeira 'Prata Anã' (AAB) em dois ciclos de produção (Juazeiro,

Bahia). Revista Ceres, Viçosa, v. 60, n. 1, p. 122-126.

https://dx.doi.org/10.1590/S0034-737X2013000100017 
SILVA, M. J. R.; JESUS, P. R. R.; ANJOS, J. M. C.; MACHADO, M.; RIBEIRO, V. G. R. Caracterização agronômica e pós-colheita das bananeiras 'Maravilha' e 'Preciosa' no Submédio do Vale São Francisco. Revista Ceres, Viçosa, v. 63, p. 46-53, 2016. http://dx.doi.org/10.1590/0034-737X2016630100

ROSA, Andrea Ribeiro Domingues. Desempenho agronômico de novas cultivares de bananeira (Musa spp.) na região de Piracicaba-SP. 2016.101 f. Tese (Doutorado em Ciências) - Curso de Pós-Graduação em Fitotecnia, Escola Superior de Agricultura "Luiz de Queiroz", Piracicaba, 2016.

http://www.teses.usp.br/teses/.../11/.../Andrea_Ribeiro_Domingues_Rosa_versao_revisada.pdf

SINGH, D. The relative importance of characters affecting genetic divergence. The Indian Journal of Genetics and Plant Breeding, New Delhi, v. 41, p. 237-245, 1981.

TONK, F. A., ILKER, E., TOSUN, M. Evaluation of genotype $\mathrm{x}$ environment interactions in maize hybrids using GGE biplot analysis. Crop Breeding and Applied Biotechnology, Viçosa, v. 11, n. 1, p. 01-09, Mar. 2011. http://www.scielo.br/scielo.php?script=sci_arttext\&pid=S1984 70332011000100001\&lng=en\&nrm=iso

TREVELYAN, W. E.; HARRISON, J. S. Studies on yeast metabolism. 1. Fractionation and microdetermination of cell carbohydrates. Biochemical Journal, London, v. 50, n. 1, p.298-3-3, 1952. https://doi.org/10.1042/bj0500298

SRIVASTAVA, S.; SHARMA, P. K., GURU, K. Nutraceuticals: a review. Journal of Chronotherapy and Drug Delivery, Davangere, v. 6, p. 1-10, 2015.

http://www.chronotherapyjournal.net/website_up/issues/JChrDD_6(1)_2015_Jan_Apr/JChrDD_6(1)_2015_001 .pdf 